\title{
IN-SERVICE PRIMARY SCHOOL TEACHERS' ACCOUNT OF PHONETICALLY DIFFICULT WORDS IN ENGLISH AS A FOREIGN LANGUAGE
}

\author{
OLEKSANDR KAPRANOV \\ Western Norway University of Applied Sciences \\ oleksandr.kapranov@hvl.no
}

\begin{abstract}
This article presents and discusses a mixed-method study that seeks to establish a set of words in the English language that in-service primary school teachers consider difficult to pronounce by young learners of English whose first language (L1) is Norwegian. In the study, 26 in-service primary school teachers of English as a Foreign Language (EFL) are asked to write a reflective essay with a list of phonetically difficult words (henceforth PDWs) in English that they think are difficult to pronounce by young EFL learners. Additionally, the in-service primary school teachers (further - participants) are requested to reflect and comment on PDWs, and explain the reasons why they think they are phonetically difficult. The participants' individual lists of PDWs are compiled into a corpus which is processed in the Statistical Package for Social Sciences (SPSS) in order to calculate the frequency of PDWs. The participants' comments and reflections are subsequently analysed qualitatively in order to establish the sources of PDWs. The results of the investigation reveal that the corpus of PDWs is comprised of 257 lexical items. The most frequent PDWs are associated with those sounds of the English language that are absent in the young EFL learners' L1, Norwegian, e.g., $/ \theta /$ in birthday, $/ ð /$ in this, $/ \mathrm{z} /$ in zoo, etc. Other frequent PDWs are related to English spelling conventions (e.g., fruit), the word-initial position of affricates (e.g., chocolate), and word stress (e.g., window). These findings and their linguo-didactic implications are further discussed in the article.
\end{abstract}

Keywords: English as a foreign language (EFL), in-service EFL teachers, phonetically difficult words (PDWs), young EFL learners

\section{Introduction}

This article outlines a mixed-method study that seeks to establish those words in the English language that in-service primary school teachers of English as a foreign language (EFL) consider difficult to pronounce by young EFL learners whose first language (L1) is Norwegian. This study is related to the overarching theme of the journal Research in Language (RiL) that reflects the scientific „crosswords between Eastern and Western Europe and between the Slavic and the Anglo-American tradition" (cf. Research in Language 2019). In concert with the RiL's ethos, the present study is informed by the Eastern European research 
tradition initiated by Sobkowiak (2002) and Szpyra-Kozłowska (2011, 2012), respectively, who focus on ,a number of specific "difficult words" in English, which are notoriously mispronounced by Polish learners, including the advanced ones" (Porzuczek and Rojczyk 2017: 314). Whilst there is a substantial number of publications that examine phonetically difficult words (henceforth - PDWs) in English by those learners whose L1s are Polish (Nowacka 2016; SzpyraKozłowska 2011, 2012; Szpyra-Kozłowska and Stasiak 2010), Slovak (Metruk 2018), and Ukrainian (Parashchuk 2017), research associated with PDWs in oral discourse by Norwegian L1 EFL learners is under-represented (Rugesæter 2014).

From a theoretical perspective, the study further described in the article is related to a well-researched topic of pronunciation difficulties encountered by young EFL learners in their learning trajectory to master oral communication in English (Brinton, Celce-Murcia, and Goodwin 2010; Copland, Garton, and Burns 2014; Rogerson-Revell 2011; Jarosz 2019). Whereas oral communication is thought of as a difficult skill to acquire by the majority of EFL learners (Zhang 2009), PDWs appear to exacerbate the process of acquisition of this skill. In this regard, it seems pertinent to mention the argument made by Porzuczek and Rojczyk (2017), who suggest that "difficult words" appear to be more difficult for less proficient learners" (Porzuczek and Rojczyk 2017: 321). Extending this suggestion further, I argue that PDWs pose a complex problem to young EFL learners, in particular, to primary school EFL learners. I agree with Szpyra-Kozłowska (2011), who indicates that PDWs

are highly detrimental to successful communication in that they significantly decrease the speaker's comprehensibility and intelligibility, create an impression of a foreign accent and are irritating for the listeners. (...) Consequently, such items deserve to be thoroughly investigated and pedagogically prioritized (Szpyra-Kozłowska 2011: 285).

A linguo-didactic focus on PDWs is in concert with the shift from the study of individual sounds (i.e. segmental phenomena) to the attention to words and strings of discourse (i.e. suprasegmental phenomena) in the teaching and learning of EFL pronunciation (Tergujeff 2012). Arguably, there is a correlation between the teaching and learning of pronunciation and the occurrence of PDWs in oral discourse produced by EFL learners (Szpyra-Kozłowska 2011). In this regard, Rugesæter (2012) posits that "it is vital in the language classroom for the teacher to understand and reflect on the problems concerning individual words" (Rugesæter 2012: 122). Currently, however, there are insufficient studies that involve EFL teachers' reflections on PDWs. In this article, I will present and discuss a mixed-method investigation of a group of in-service EFL primary school teachers (further - participants), who reflect upon their classroom encounters with PDWs in oral classroom discourse by young EFL learners in the Years 3-7 of Norwegian primary schools. 
The present article is structured as follows. First, an overview of previous studies associated with PDWs in EFL will be provided. Second, an outline of EFL teaching and learning in Norwegian primary school contexts will be discussed. Thereafter, I will introduce and discuss the present study and its research aims (section 2), participants (subsection 2.1), procedure and methods (subsection 2.2), the corpus of the study (subsection 2.3), results (subsection 2.4) and discussion of the major findings (subsection 2.5). Finally, the article will be concluded with the summary of the findings and their linguo-didactic implications in section 3 .

\subsection{Previous Studies Associated with PDWs in EFL}

There is a substantial body of previous research associated with PDWs in EFL studies (Nowacka 2016; Parashchuk 2017; Szpyra-Kozłowska 2011, 2012). Apart from EFL, the notion of PDWs is employed in other disciplines, for instance, in speech pathology, especially in relation to speech production of people who stutter (Howell et al. 2006), and in developmental studies, where PDWs are addressed within the issue of monolingual speech acquisition (Trecca et al. 2019). Current research in the aforementioned scientific fields suggests that there is a range of variables that are involved in the pronunciation of PDWs by monolingual and bilingual population, as well as by EFL learners. These variables involve word stress, the length of the word, its position in the sentence and/or utterance, its frequency and the word-initial phoneme (Howell et al. 2006; Rugesæter 2012; Wingate 2002).

As far as the studies of PDWs in EFL learner cohorts are concerned, there is a seminal line of scientific enquiry into this issue (Metruk 2018; Nowacka 2016; Parashchuk 2017; Szpyra-Kozłowska 2011). The studies that have been conducted by Szpyra-Kozłowska $(2011,2012)$ are of particular importance for the present investigation, since it seeks to employ Szpyra-Kozłowska's (2011) methodology of examining subjective evaluations of PDWs. In her study, Szpyra-Kozłowska (2011) requests Polish L1 EFL learners on the intermediate level of proficiency to provide a list of the words that they consider difficult to pronounce. The analysis of the participants' word lists reveals that PDWs are caused by the following problems: i) phonetic 'false friends'; ii) spelling-based forms; iii) word stress; iv) difficult consonants clusters; v) longer words; vi) liquids; vii) alternating forms; and viii) high front vowels. Szpyra-Kozłowska (2011) indicates that PDWs in the study involve subjective judgements; hence they should be treated with caution and should be supplemented by a study that examines whether or not those PDWs actually occur in the learners' oral discourse.

In the subsequent experimental study, Szpyra-Kozłowska (2012) tests her previous assumption concerning the use of PDWs in Polish L1 EFL learners' speech. The experiment in Szpyra-Kozłowska (2012) involves 20 advanced EFL learners who are asked to read aloud a list of sentences with 80 PDWs in order 
to identify the types of errors and ascertain the level of difficulty associated with those PDWs. The results of the study reveal that the sources of PDWs "involve sequences of high front vowels, clusters of interdentals with other fricatives and phonetic 'false friends"' (Szpyra-Kozłowska 2012: 253).

In the wake of the studies conducted by Szpyra-Kozłowska (2011, 2012), Porzuczek and Rojczyk (2017) investigate how word stress impacts upon the level of pronunciation difficulties experienced by Polish L1 EFL learners. Porzuczek and Rojczyk (2017) argue that explicit instruction in the teaching and learning of word stress in English involves the „focus on individual vocabulary items" (Porzuczek and Rojczyk 2017: 315) that might appear problematic to pronounce by the learners. By means of using a list of PDWs (e.g., surface, Japan, success, industry, etc.), Porzuczek and Rojczyk (2017) examine the learners' strategies of word stress realisation. The results of their study suggest that the learners' stress identification in PDWs "does not form a predictable pattern, suggesting that Polish learners often ignore or do not recognize word stress as an intrinsic lexical property" (Porzuczek and Rojczyk 2017: 322).

Similarly to Porzuczek and Rojczyk (2017), Parashchuk (2017) seeks to establish how stress is associated with PDWs in oral discourse of adult EFL students. The study conducted by Parashchuk (2017) involves a group of preservice EFL teachers whose L1 is Ukrainian. They are asked to write transcriptions of PDWs in the International Phonetic Alphabet (IPA) and to pronounce PDWs represented by the so-called internationalisms, i.e. those words of Latin and Greek origin that are present both in the English and Ukrainian languages. Parashchuk (2017) indicates that the main cause of PDWs in the participants' oral discourse rests with the stress patterns that are typically used in the Ukrainian language. Parashchuk (2017) suggests that the participants' problems with PDWs eventuate from the negative transfer from Ukrainian into English.

Whereas Parashchuk (2017), as well as Porzuczek and Rojczyk (2017), prioritise word stress in relation to PDWs, the studies conducted by Nowacka (2016) and Metruk (2018), respectively, explore the relationship between PDWs and segmentals/suprasegmentals. Specifically, Nowacka (2016) employs a list of 60 PDWs in order to explore the occurrence of local and global errors in their production and recognition. The results of the study reveal that the most frequent PDWs are associated with a number of segmental units, such as affixes -age, -ate, and -ous. Metruk (2018) investigates the pronunciation of PDWs and suprasegmentals with word-initial sounds $/ \mathrm{v} /$ and $/ \mathrm{w} /$ in oral discourse in English by Slovak L1 adult EFL learners. The results of the study by Metruk (2018) reveal that Slovak L1 EFL learners' pronunciation of PDWs is associated with the substitution of $/ \mathrm{v} /$ for $/ \mathrm{w} /$ and vice versa. 


\subsection{EFL in Norwegian Primary School Contexts}

Prior to proceeding to the analysis of PDWs in the present study, it should be explained how EFL teaching and learning is organised in Norwegian primary school contexts. Primary schooling in Norway lasts for seven years, comprising Year 1 till Year 7 (or, in American classification, grade 1 till grade 7). In Norway, English as a subject is compulsory from Year 1 of primary school to Year 10 in lower secondary school (Bakken and Lund 2018; Drew, Oostdam, and Han van Toorenburg, 2007). It means that English is taught in Norwegian primary schools starting from the age of six. The total number of hours assigned to English as a school subject during compulsory education (i.e., between Year 1 and year 10) is 527 hours (Drew, Oostdam, and Han van Toorenburg, 2007: 322). From Year 1 to Year 4 of primary school, there are 138 teaching hours allocated for English, whilst "from Years 5 to 7 the number of teaching hours increases to 228" (Scheffler et al. 2018: 134). With this allocation of teaching hours, primary schools in Norway typically offer English lessons once a week (Rugesæter 2014).

The current literature in EFL studies indicates that English is regarded as an essential international language in Norway (Rugesæter 2012: 120). Research suggests that "the level of English language skills among Norwegians is generally considered to be high" (Drew 2009: 110). In Norway, English is characterised by a prestigious status, and "exposure to the language, especially through TV, film and radio, is widespread" (Drew 2009: 110).

The importance of EFL teaching and learning in Norwegian primary school contexts is evident from the Norwegian school reform (in the Norwegian language - Kunnskapsløftet, or abbreviated as LK06). One of the foci of the LK06 involves the introduction of new approaches to EFL in the Norwegian public school system in order to

develop one national curriculum for the subject of English and another one for all other foreign languages. English is no longer considered a foreign language, but has become almost a second language for pupils in Norwegian schools. Competence in English is taken for granted by today's younger generation. (Speitz 2012: 12)

In accordance with the LK06 regulations, the teaching and learning of English, as well as other subjects, should focus upon five basic skills, e.g. being able to express oneself in writing and orally, reading, numeracy, and being able to use digital tools (Mellegård and Pettersen 2012: 210). Within the context of the LK06 regulations, special emphasis is placed on the development of the communicative competence of EFL learners (Rugesæter 2012: 120). It is logical to assume that young EFL learners' communicative competence in terms of their oral skills should involve attention to pronunciation. The current approach to pronunciation in Norwegian primary schools involves the development of 
a pronunciation that is clear and good enough to make them able to communicate efficiently in English. The underlying goal must be to make sure that they have a pronunciation that does not disadvantage them as speakers of English as an L2. (Rugesæter 2012: 120)

Whereas it is inferred from LK06 that the teaching and learning of English pronunciation should be important, it does not seem to play a central role in EFL as a subject in Norwegian primary schools (Bakken and Lund 2018; Drew, Oostdam, and Han van Toorenburg, 2007). An epiphenomenal status of English pronunciation is explained by "the nearness of the phonological systems of English and Norwegian, both being Germanic languages" (Rugesæter 2012: 121). This observation is echoed by a research study conducted by Olsen (1999), who posits that "Norwegians have a reputation for learning English easily since their first language facilitates the learning" (Olsen 1999: 192).

Whilst an intensive teaching and learning of English pronunciation does not appear topical owing to the genetic closeness of English and Norwegian and the out-of-school exposure to English by means of mass media (Drew, Oostdam, and Han van Toorenburg, 2007; Rugesæter 2014), an EFL young learner does encounter difficulties associated with pronunciation of individual English sounds and suprasegmental units (Rugesæter 2012). In the subsequent sections of this article, I will present and discuss a mixed-method study that addresses how inservice EFL primary school teachers reflect and identify PDWs in oral classroom discourse produced in English by their primary school students.

\section{The Present Study}

The present study seeks to provide insight into PDWs in oral classroom discourse by EFL primary school learners whose L1 is Norwegian. This is done by means of requesting the participants to write a list of PDWs that they have observed to occur in oral classroom discourse by young EFL learners whose L1 is Norwegian. The notion of oral classroom discourse in this study follows the definition proposed by Walsh (2011), who argues that classroom discourse involves "the complex relationship between language, interaction and learning" (Walsh 2011: 1) that is asymmetrical and dynamic. Arguably, the asymmetrical relationship in oral classroom discourse, among other aspects, may involve the participants' awareness of and attention to those PDWs that are, predominantly, not noticed by young EFL learners. Hence, the asymmetry arises out of the participants' ability to identify, and, presumably, reflect upon a PDW, whereas a young EFL learner does not possess this ability yet. It could be argued that the dynamic aspect of oral classroom discourse is manifested by a series of EFL classroom interactions that differ from each other. As anecdotal evidence suggests, there are no identical EFL classrooms and the teacher's oral 
interactions with the student/students appear to be different due to a number of dynamic variables, such as the student's/students' age, cognitive abilities, the level of language mastery, gender, family background, possible behavioural challenges, etc.

Based upon the aforementioned view of oral classroom discourse as an asymmetrical and dynamic discursive space (Walsh 2011), the present study involves an assumption that the participants would exhibit awareness of PDWs in oral classroom discourse by young EFL learners in the Years $3-7$ of primary school. It is assumed in the study that the participants' essays on the topic „My Reflections upon English Words that are Difficult to Pronounce by Young EFL Learners" would be reflective of a range of instances where the participants have encountered PDWs in oral classroom discourse by young EFL learners in the Years $3-7$ of Norwegian primary schools. The specific research aims of the study are as follows:

i) to examine the lists of PDWs provided by the participants;

ii) to analyse whether of not there would be PDWs common to the participants;

iii) to analyse a possible range of sources that cause PDWs.

\subsection{Participants}

In total, 26 participants ( $\mathrm{M}$ age $=40$ year old, $\mathrm{STD}=8,1$ ) took part in the study. All participants were female in-service primary school teachers, who taught English in the Years $3-7$. The participants' mean period of teaching experience was estimated to be 16 years in accordance with the answers provided by them in the background questionnaire survey. All participants indicated that Norwegian was their L1 and English was their FL. There were neither bilinguals nor English L1 speakers in the study. The participants signed the consent form that allowed the author of the article to collect and process their written data for scientific purposes. To ensure confidentiality, the participants' real names and other identifying information were coded (the participants' codes were $\mathrm{P}$ as in participant and the number, for example P 1, P 2,.., P 26).

\subsection{Procedure and methods}

The study followed the methodological framework described in SzpyraKozłowska (2011). Specifically, the study employed Szpyra-Kozłowska's (2011) approach to the subjective evaluation of PDWs. In accordance with Szpyra-Kozłowska (2011), the participants in the study were instructed to provide a list of PDWs and comment on them. However, the critical difference between the present study and that of Szpyra-Kozłowska (2011) involved the following consideration. Whereas PDWs in Szpyra-Kozłowska's study (2011) were subjectively self-evaluated by EFL learners themselves, the present investigation involved EFL teachers' evaluations of those PDWs that occurred in 
oral classroom discourse produced by young EFL learners in the Years $3-7$ of primary school.

The procedure in the study was as followed. The participants were asked to write a reflective essay on the topic „My Reflections upon English Words that are Difficult to Pronounce by Young EFL Learners". The essay length was suggested to be between 600 and 800 words. The participants were instructed that in their reflective essays they should write a list of PDWs that occurred in young EFL learners' oral classroom discourse and provide explicit comments on those words. The participants were instructed that they had three months to complete the essay writing and send the essay electronically to the author of the article.

\subsection{The Corpus}

The participants' reflective essays were collapsed into one file and analysed in the Statistical Package for Social Sciences (SPSS). The results of the descriptive statistics of the corpus were summarised in Table 1 below.

Table 1. The Descriptive Statistics of the Corpus

\begin{tabular}{|c|l|l|}
\hline $\mathbf{N}$ & \multicolumn{1}{|c|}{ Statistical measures } & Statistical values \\
\hline 1. & Total number of words & 16904 \\
\hline 2. & Mean words & 650 \\
\hline 3. & Standard deviation & 182 \\
\hline 4. & Minimum & 157 \\
\hline 5. & Maximum & 1011 \\
\hline
\end{tabular}

The corpus was comprised of the participants' reflective essays that included the lists of PDWs (total $\mathrm{N}$ of words $=16$ 904). The participants' combined lists of PDWs consisted of 257 words that they considered challenging to pronounce by young EFL learners in the Years $3-7$ of primary school.

\subsection{Results}

The analysis of the participants' lists of PDWs has yielded the results that are summarised in Table 2 below. 
Table 2. The Participants' Account of PDWs in Young EFL Learners' Oral Classroom Discourse in English

\begin{tabular}{|l|l|l|}
\hline $\mathbf{N}$ & N of Occurrence & PDWs \\
\hline 1. & $\mathrm{~N}=8$ & Birthday, this, three, zoo \\
\hline 2. & $\mathrm{~N}=7$ & Think \\
\hline 3. & $\mathrm{~N}=6$ & Through, dogs, thirty \\
\hline 4. & $\mathrm{~N}=5$ & Very, wet \\
\hline 5. & $\mathrm{~N}=4$ & Chair, both, throw, sixth, third \\
\hline 6. & $\mathrm{~N}=3$ & $\begin{array}{l}\text { Bath, bathroom, does, Earth, eyes, father, fifteenth, health, just, } \\
\text { lives, mirror, mother, said, them, thin, together, thousand, truth }\end{array}$ \\
\hline 7. & $\mathrm{~N}=2$ & $\begin{array}{l}\text { Again, apple, autumn, eggs, fifteen, fifth, height, jam, keys, kids, } \\
\text { kings, knee, knew, knife, laugh, pays, peas, please, something, } \\
\text { teeth, thanks, thirteen, thirteenth, those, thunder, Thursday, walk, } \\
\text { went }\end{array}$ \\
\hline 8. & $\mathrm{~N}=1$ & $\begin{array}{l}\text { Away, bird, break, building, cheap, cheese, chocolate, clothes, } \\
\text { dads, enough, February, fever, flight, forward, fruit, half, halves, } \\
\text { her, heart, inside, jaw, jelly, Jack, Jim, joke, juice, June, lies, light, } \\
\text { London, murder, muscle, needs, night, outside, pies, plays, } \\
\text { pleased, present, prize, runs, salad, should, south, talk, that, the, } \\
\text { thought, toothpaste, tree, twenty, vase, vegetable, water, wave, } \\
\text { well, window, word, writing, zebra }\end{array}$ \\
\hline
\end{tabular}

Table 3 below summarises the participants' comments and explanations of the reasons associated with occurrence of PDWs in English in oral classroom discourse by young EFL learners in the Years 3-7 of primary school.

Table 3. The Participants' Comments on PDWs in Oral Classroom Discourse by Young EFL Learners in the Years 3-7 of Primary School

\begin{tabular}{|c|c|c|c|}
\hline $\mathbf{N}$ & Comments concerning PDWs & Examples & $\begin{array}{l}\text { Percentage of } \\
\text { participants } \\
\text { who made the } \\
\text { comment }\end{array}$ \\
\hline 1. & $\begin{array}{l}\text { The absence of the inter-dental } \\
\text { consonant sounds } / \theta / \text { and } / ð / \text { in } \\
\text { Norwegian }\end{array}$ & $\begin{array}{l}\text { /tri:/ instead of / } \theta \text { ri:/ in three; } \\
/ \mathrm{dem} / \text { instead of /ðem/ in them; }\end{array}$ & $70 \%$ \\
\hline 2. & $\begin{array}{l}\text { The absence of the consonant } \\
\text { sound /z/ in Norwegian }\end{array}$ & $\begin{array}{l}\text { /su:/ instead of /zu:/ in zoo; } \\
\text { /dpgs/ instead of /dpgz/ in dogs; }\end{array}$ & $62 \%$ \\
\hline 3. & $\begin{array}{l}\text { The use of the Norwegian } \\
\text { uvular rhotic /ь/ instead of /r/ }\end{array}$ & $\begin{array}{l}\text { /'tьи:/ instead of /9ru:/ in through; } \\
\text { /'mıьə/ instead of /'mirə/ in } \\
\text { mirror; }\end{array}$ & $38 \%$ \\
\hline 4. & $\begin{array}{l}\text { The absence of the bilabial /w/ } \\
\text { sound in Norwegian resulting } \\
\text { in the substitution of /w/ for } / \mathrm{v} / \\
\text { and vice versa }\end{array}$ & $\begin{array}{l}\text { /vet/ instead of /wet/ in wet; } \\
\text { /wa:s/ instead of/va:z/ in vase; }\end{array}$ & $35 \%$ \\
\hline
\end{tabular}




\begin{tabular}{|c|c|c|c|}
\hline 5. & $\begin{array}{l}\text { The use of the Norwegian } \\
\text { sound } / \varnothing / \text { instead of the } \\
\text { English sound /3:/ }\end{array}$ & $\begin{array}{l}\text { /'bøtdeI/ instead of /'b3:Odel/ in } \\
\text { birthday; } \\
\text { /hø/ instead of /hз:/ in her; }\end{array}$ & $31 \%$ \\
\hline 6. & English spelling & $\begin{array}{l}\text { /fru:It / instead of /fru:t/ in fruit; } \\
\text { /ju:n/ instead of /dzu:n/ in June; } \\
\text { /a'gen/ instead of /a'gen/ in again; }\end{array}$ & $31 \%$ \\
\hline 7. & $\begin{array}{l}\text { The word-initial position of the } \\
\text { English consonant }\end{array}$ & $\begin{array}{l}\text { / } \mathrm{fea} / \text { instead of } / \mathrm{t} \mathrm{fea} / \text { in chair; } \\
/ \int \mathrm{i}: \mathrm{s} / \text { instead of } / \mathrm{t} \mathrm{f}: \mathrm{z} / \text { in cheese; }\end{array}$ & $15 \%$ \\
\hline 8. & Word stress & $\begin{array}{l}\text { /vedz'terbl/ instead of /'vedztəbl/ } \\
\text { in vegetable; } \\
\text { /win'dəo/ instead of /'windəo/ in } \\
\text { window }\end{array}$ & $8 \%$ \\
\hline
\end{tabular}

\subsection{Discussion}

As seen in Table 2, the participants mention several PDWs that frequently occur in the corpus. In particular, the most frequent PDWs are associated with the interdental consonant sounds $/ \delta /$ and $/ \theta /$, as well as with the contrast $/ \mathrm{s} /-/ \mathrm{z} /$, for example birthday ( $\mathrm{N}$ of occurrence $=8)$, this $(\mathrm{N}=8)$, three $(\mathrm{N}=8)$, and zoo $(\mathrm{N}$ $=8$ ). These PDWs are followed by PDWs with the contrast $/ \mathrm{w} /-/ \mathrm{v} /$, for instance very $(\mathrm{N}=5)$ and wet $(\mathrm{N}=5)$, respectively.

Whereas the results demonstrate that there are no PDWs that are common to all participants, it is evident from the corpus that they frequently refer to similar sources of PDWs in young EFL learners' oral classroom discourse. Specifically, the most frequent sources of PDWs are attributed by the participants to the absence of the consonant sounds $/ \theta /, / \mathrm{d} /$, and $/ \mathrm{z} /$ in the Norwegian language. Other sources of PDWs according to the participants are illustrated by Figure 1 below.

Figure 1. Sources of PDWs in Young EFL Learners' Oral Classroom Discourse

\section{Sources of PDWs in Young EFL Learners' Oral Classroom Discourse}

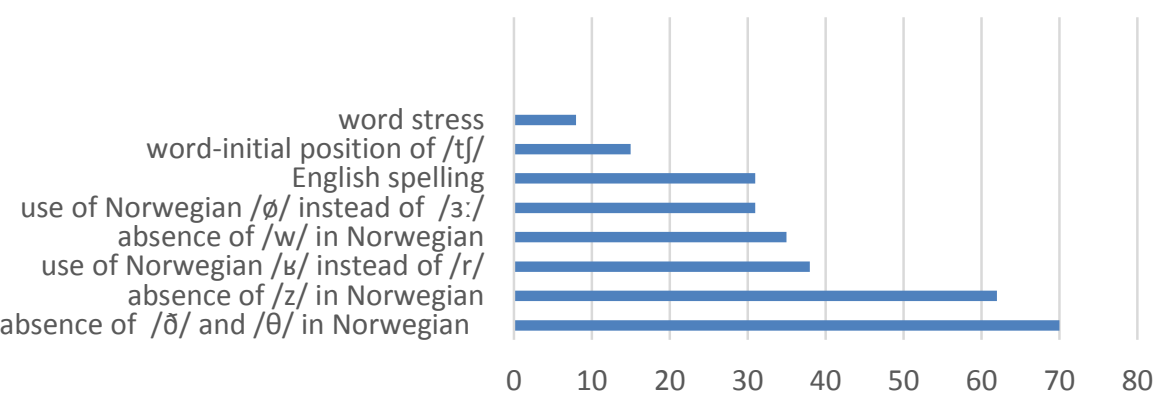


It is evident in Figure 1 that in addition to the sounds that do not exist in Norwegian (e.g., /3:/, / / /, / $/ /, / r /, / z /$, and $/ \mathrm{w} /$ ), the participants refer to English spelling as a source of PDWs (e.g., mute letters, spelling conventions associated with the English letter $\mathrm{j}$, and the neutral vowel schwa, respectively). Additionally, the participants observe that the word-initial position of the English affricate sound /t $\mathrm{f} / \mathrm{can}$ be accounted as a source of PDWs that are challenging to pronounce by young EFL learners in the Years $3-7$ of primary school. Another source of PDWs is attributed by the participants to word stress. Further in the article, the participants' comments and reflections upon PDWs will be discussed through the lenses of the following variables: i) the sounds of the English language that do not exist in Norwegian (see subsection 2.5.1 of the article); ii) the impact of the English spelling system upon PDWs (subsection 2.5.2); iii) the word-initial position of the English sound /t $\mathrm{f} /$ in PDWs (subsection 2.5.3); and iv) stress in PDWs (subsection 2.5.4).

\subsubsection{PDWs that are associated with the English sounds that do not exist in Norwegian}

It can be seen in Table 3 that the participants' comments and reflections upon the sources of PDWs in young EFL learners' oral classroom discourse involve a number of English sounds that are not found in the Norwegian language, the learners' L1, e.g., /3:/, / $/ \theta /, / \delta /, / \mathrm{r} /, / \mathrm{z} /$, and $/ \mathrm{w} /$. These sounds are not present in the official varieties of the Norwegian language, bokmål (the variety of Oslo and Eastern parts of Norway) and nynorsk which is spoken in Western Norway and in the North of the country, as well as in all other dialects of Norwegian (Rugesæter 2012).

The analysis of the participants' reflective essays indicates that $70 \%$ of the participants associate the source of PDWs in young EFL learners' oral classroom discourse with the absence of the inter-dental consonant sounds $/ \theta /$ and $/ \delta /$ in Norwegian, for instance in such PDWs as birthday $(\mathrm{N}=8)$, this $(\mathrm{N}=8)$, three $(\mathrm{N}$ $=8)$, think $(\mathrm{N}=7)$, through $(\mathrm{N}=6)$, thirty $(\mathrm{N}=6)$, both $(\mathrm{N}=4)$, throw $(\mathrm{N}=4)$, sixth $(\mathrm{N}=4)$, third $(\mathrm{N}=4)$, bath $(\mathrm{N}=3)$, bathroom $(\mathrm{N}=3)$, Earth $(\mathrm{N}=3)$, father $(\mathrm{N}=3)$, fifteenth $(\mathrm{N}=3)$, health $(\mathrm{N}=3)$, them $(\mathrm{N}=3)$, thin $(\mathrm{N}=3)$, together $(\mathrm{N}$ $=3)$, thousand $(\mathrm{N}=3)$, truth $(\mathrm{N}=3)$, fifth $(\mathrm{N}=2)$, something $(\mathrm{N}=2)$, teeth $(\mathrm{N}=$ $2)$, thanks $(\mathrm{N}=2)$, thirteen $(\mathrm{N}=2)$, thirteenth $(\mathrm{N}=2)$, those $(\mathrm{N}=2)$, thunder ( $\mathrm{N}$ $=2)$, Thursday $(\mathrm{N}=2)$, south $(\mathrm{N}=1)$, that $(\mathrm{N}=1)$, the $(\mathrm{N}=1)$, thought $(\mathrm{N}=1)$, toothpaste $(\mathrm{N}=1)$. Typically, the participants account for the source of these PDWs by referring to the young EFL learners' L1, Norwegian, as seen in excerpt (1) below

(1) I can see a pattern among my pupils... Words with $<$ th $>$ are the hardest words to pronounce and the reason for that is that we do not have $/ \theta /$ or $/ ð /$ in the Norwegian language. Most of my pupils say <trow> (throw), $<$ tunder> (thunder), <batroom> (bathroom), <togeder> (together), <dat> (that), <dis > (this), and <dose > (those). (Participant P 5) 
These findings lend indirect support to the study conducted by SzpyraKozłowska (2011), who reports that the interdentals and, especially, the clusters of interdentals are challenging to pronounce by EFL learners whose L1 does not contain interdental consonants, for instance, Polish.

The analysis of the participants' reflective essays points to the absence of the lenis fricative consonant / $\mathrm{z} /$ in young EFL learners' L1 as a substantial source of PDWs (see Table 3). In their comments, the participants provide several instances of PDWs that contain the English sound /z/, which young EFL learners substitute for $/ \mathrm{s} /$, for instance zoo $(\mathrm{N}=8), \operatorname{dogs}(\mathrm{N}=6)$, does $(\mathrm{N}=3)$, eyes $(\mathrm{N}=$ $3)$, lives $(\mathrm{N}=3)$, thousand $(\mathrm{N}=3)$, eggs $(\mathrm{N}=2)$, keys $(\mathrm{N}=2)$, kids $(\mathrm{N}=2)$, kings $(\mathrm{N}=2)$, pays $(\mathrm{N}=2)$, peas $(\mathrm{N}=2)$, please $(\mathrm{N}=2)$, and other PDWs with the $\mathrm{N}$ of occurrence $=1$ (e.g., dads, halves, lies, needs, pies, plays, pleased, prize, and runs). The participants indicate that since the sound $/ \mathrm{z} /$ is not found in Norwegian, the young learners' L1, they experience difficulties with both the pronunciation of the words that contain / $\mathrm{z} /$, as well as with the auditory discrimination of the contrast $/ \mathrm{s} /-/ \mathrm{z} /$, as evident from excerpt (2), e.g.:

(2) The most difficult words to pronounce correctly are the ones with z. My students do not pronounce this sound automatically in their English... There are two aspects of the difficulty of this sound. The first one is how to make the sound, and the second one is when to use it. (Participant P 21)

This finding is in contrast with the literature outlined in section 1.1 of the present article. Specifically, the prior studies on PDWs conducted by Metruk (2018), Nowacka (2016), Parashchuk (2017), and Szpyra-Kozłowska (2011; 2012) do not seem to report instances of PDWs that are ascribed to the $/ \mathrm{s} /-/ \mathrm{z} /$ contrast and/or the auditory discrimination of the sound $/ z /$. This can be explained by the fact that L1s (e.g., Polish, Slovak, and Ukrainian) of the participants in those studies are characterised by the presence of $/ \mathrm{z} /$, whereas this sound does not exist in the Norwegian language.

The use of the Norwegian uvular rhotic sound /ь/ instead of the English /r/ is deemed to be one of the causes of PDWs by $38 \%$ of participants. They posit that $/ \mathrm{r} /$ is routinely substituted by young EFL learners for $/ \mathrm{s} /$, which is typically found in the dialects of Western and Southern Norway, where the participants and their primary school students hail from. Commenting upon those PDWs that are associated with the English sound $/ \mathrm{r} /$, one of the participants suggests that such PDWs as mirror are "challenging because of the heavy presence of the letter " $r$ "; the type of $/ \mathrm{r}$ / in the English language is different from the $/ \mathrm{r} / \mathrm{we}$ find in the Norwegian language" (participant P 20). The PDWs that the participants explicitly comment upon as challenging to pronounce due to the presence of the English sound $/ \mathrm{r} /$ are birthday $(\mathrm{N}=8)$, through $(\mathrm{N}=6)$, thirty $(\mathrm{N}=6)$, very $(\mathrm{N}=$ 5), throw $(\mathrm{N}=4)$, bathroom $(\mathrm{N}=3)$, Earth $(\mathrm{N}=3)$, father $(\mathrm{N}=3)$, mother $(\mathrm{N}=$ $3)$, together $(\mathrm{N}=3)$, truth $(\mathrm{N}=3)$, mirror $(\mathrm{N}=3)$, Thursday $(\mathrm{N}=2)$, February $(\mathrm{N}=1)$, break $(\mathrm{N}=1)$, runs $(\mathrm{N}=1)$, tree $(\mathrm{N}=1)$, and writing $(\mathrm{N}=1)$. 
According to $35 \%$ of the participants, the absence of the bilabial sound $/ \mathrm{w} /$ in young learners' L1 (Norwegian) often results in the substitution of $/ \mathrm{w} /$ for $/ \mathrm{v} /$ and vice versa, as explained by participant P 4, e.g. "Some of my students also find it difficult to pronounce the words "water", "wet", "went", "very" and "well". My experience shows that my students tend to $\operatorname{mix} / \mathrm{v} /$ and $/ \mathrm{w} /$ " (Participant $\mathrm{P} 4)$. In addition to the frequent PDWs very $(\mathrm{N}=5)$ and wet $(\mathrm{N}=$ $5)$, the participants mention such PDWs as walk $(\mathrm{N}=2)$, fever $(\mathrm{N}=1)$, twenty $(\mathrm{N}=1)$, wave $(\mathrm{N}=1)$, and well $(\mathrm{N}=1)$.

Notably, the participants refer to only one English vowel sound that they deem to be amongst the sources of difficulties in PDWs, namely the English mid central vowel /3:\%. In particular, $31 \%$ of the participants posit that young EFL learners whose L1 is Norwegian appear to substitute /3:/ for the Norwegian sound / $\varnothing$ / in such PDWs, as birthday $(\mathrm{N}=8)$, thirty $(\mathrm{N}=6)$, third $(\mathrm{N}=4)$, Earth $(\mathrm{N}=3)$, bird $(\mathrm{N}=1)$, her $(\mathrm{N}=1)$, murder $(\mathrm{N}=1)$, and word $(\mathrm{N}=1)$.

\subsubsection{PDWs that are associated with English spelling}

The system of English spelling is considered to be among the sources of PDWs by $31 \%$ of the participants. They appear to comment upon the spelling of mute letters, the spelling of the English neutral sound schwa, and the spelling of $\mathrm{j}$, respectively. The participants refer to mute letters in such PDWs, as said $(\mathrm{N}=$ $3)$, talk $(\mathrm{N}=3)$, autumn $(\mathrm{N}=2)$, height $(\mathrm{N}=2)$, knee $(\mathrm{N}=2)$, knew $(\mathrm{N}=2)$, knife $(\mathrm{N}=2)$, laugh $(\mathrm{N}=2)$, building $(\mathrm{N}=1)$, enough $(\mathrm{N}=1)$, flight $(\mathrm{N}=1)$, fruit $(\mathrm{N}=1)$, half $(\mathrm{N}=1)$, inside $(\mathrm{N}=1)$, muscle $(\mathrm{N}=1)$, night $(\mathrm{N}=1)$, outside $(\mathrm{N}=1)$, should $(\mathrm{N}=1)$, talk $(\mathrm{N}=1)$, and thought $(\mathrm{N}=1)$. Additionally, the participants provide examples of PDWs where the mute letters are pronounced by young EFL learners due to the existence of similar Norwegian words, e.g. knee (Norwegian kne, where / $\mathrm{k} /$ is pronounced), half (Norwegian halv, where /l/ is pronounced), inside and outside (Norwegian side, pronounced as /'sidə/). These findings are in concert with the prior studies conducted by SzpyraKozłowska (2012) and Nowacka (2016), who have established that mute letters are amongst the sources of PDWs.

As previously mentioned, there are PDWs that are associated by the participants with the spelling of the English neutral sound schwa. These PDWs are exemplified by again $(\mathrm{N}=2)$, away $(\mathrm{N}=1)$, forward $(\mathrm{N}=1)$, salad $(\mathrm{N}=1)$, and London $(\mathrm{N}=1)$. Commenting upon a number of PDWs that involve the neutral vowel schwa /ə/, one of the participants observes that

(3) Some students have difficulties with pronouncing words like salad, forward with the schwa /ə/. They pronounce schwa more like a lip rounding / $\varnothing /$ or /e/. Those words are difficult to both read and pronounce because the schwa can be spelt in so many combinations. ... This mistake does not usually impede intelligibility, but as /a/ is the most common vowel in English it is important to be able to pronounce it fairly correctly. (Participant P 9) 
Other participants suggest that schwa is not a novel phoneme to young EFL learners whose L1 is Norwegian, since "we find this sound in many Norwegian dialects, for example in words like "stoppe" and "loppe" (participant P10). However, the participants argue that the English neutral vowel schwa "can be represented in spelling by any English letter used for vowels it makes it difficult to recognize and use it correctly" (participant P13).

In regards of those PDWs that are associated with the spelling conventions of the English language, the participants remark that the spelling of the English letter $\mathrm{j}$ contributes to the mispronunciation of certain English words, especially in the word-initial position, since young EFL learners seem to confuse it with the pronunciation of the Norwegian letter $\mathrm{j}$. According to the participants, these PDWs are just $(\mathrm{N}=3)$, jam $(\mathrm{N}=2)$, jaw $(\mathrm{N}=1)$, jelly $(\mathrm{N}=1)$, Jack $(\mathrm{N}=1)$, Jim $(\mathrm{N}=1)$, joke $(\mathrm{N}=1)$, juice $(\mathrm{N}=1)$, and June $(\mathrm{N}=1)$. The participants write in their comments that young EFL learners in the Years $3-7$ routinely substitute the English consonant / $\mathrm{d}_{3} /$ for the Norwegian sound $/ \mathrm{j} /$ in the afore-mentioned words, so that, for example, the English word just /dzsst/ is pronounced by young learners as $/ \mathrm{j} \Lambda \mathrm{st} /$.

\subsubsection{PDWs that are associated with the word-initial position of the English sound /tfl}

The word-initial position of the English consonant $/ \mathrm{t} f /$ is singled out as a source of PDWs by $15 \%$ of the participants. In particular, those participants mention that the word-initial position of the sound $/ \mathrm{t} f /$ appears to be difficult to pronounce by young EFL leaners in the Years $3-7$ of primary school. Whilst the participants note that typically the English affricate /t $\mathrm{f} /$ does not appear to pose problems in other positions in the word, the word-initial position of this affricate is associated by the participants with a range of PDWs, such as chair ( $\mathrm{N}$ $=4)$, cheap $(\mathrm{N}=1)$, cheese $(\mathrm{N}=1)$, and chocolate $(\mathrm{N}=1)$.

The participants argue that the problem with such PDW as cheese consists in the substitution of the English sound /t $\mathrm{g} /$ for the Norwegian retroflex fricative $/ \mathrm{s} /$ or the English $/ \mathrm{J} /$. The participants suggest that those young learners who speak bokmål are not able to pronounce $/ \mathrm{t} / \mathrm{and} /$ or substitute it for its Norwegian equivalent /ç/ in such English words as cheese and cheap, whereas young leaners whose dialect is nynorsk can pronounce the English sound / $\mathrm{t} /$ in the word-initial position. This finding suggests a possible correlation between a young EFL learner's dialect in their L1 and PDWs in EFL. In this regard, it could be argued that the literature summarised in subsection 1.1 of this article (e.g., Nowacka 2016; Parashchuk 2017; Szpyra-Kozłowska 2011, 2012) does not address the issue of dialectal diversity in the learner's $L$ as a variable involved in speech production of PDWs in EFL. Even though the finding concerning the impact of young learners' L1 dialect upon PDWs in EFL seems to be novel, it should be approached with caution and verified in future studies. 


\subsubsection{PDWs that are associated with word stress}

As indicated in Table 3,8\% of the participants in the study regard word stress as a variable that affects PDWs in oral classroom discourse by young EFL learners. In particular, the participants refer to such PDWs as window and vegetable. They point to a typical problem that consists in the misplacement of stress on the second syllable. The participants indicate that this results in a recurring pattern of pronouncing /vedz'terbl/ instead of /'vedztəbl/ in vegetable and /win'dəo/ instead of /'windər/ in window. The source of the former PDW is explained by the participants by its similarity to the English word table. This finding is suggestive of the research results obtained by by Nowacka (2016), who has established that frequent PDWs are related to the problems with pronunciation of morphemes, in particular affixes, that are mispronounced by EFL learners. Whilst the source of the PDW vegetable is accounted for by the participant, another participant, who mentions the PDW window, provides no clarification for the frequent occurrence of this PDWs in oral classroom discourse produced by young EFL learners.

Judging from the data summarised in Table 2, it is evident that the problem of word stress seems to be restricted to the bisyllabic PDW window and the quadrisyllabic PDW vegetable. Given that the majority of the PDWs are monosyllabic words, it is, perhaps, not surprising that only $8 \%$ of the participants refer to word stress as a variable that can be accounted as a source of PDWs. Figure 1 below illustrates the syllabic structure of PDWs in the corpus.

Figure 2. The Distribution of Syllables in the Corpus of PDWs

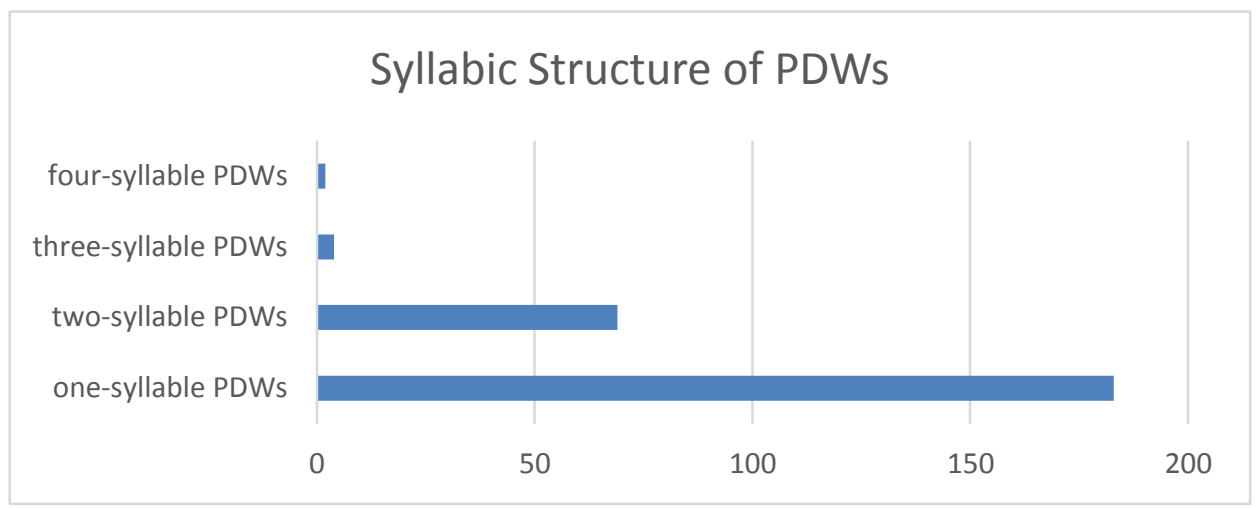

It is evident from Figure 2 that whereas polysyllabic words are frequent, the placement of word stress does not appear to be a problem that is noticed by the participants. Presumably, young EFL learners do not experience difficulties with the correct stress placement as far polysyllabic words are concerned. This finding is in contrast to the studies conducted by Szpyra-Kozłowska (2011), and 
Porzuczek and Rojczyk (2017), who have discovered that word stress plays a substantial role as a source of PDWs for Polish L1 EFL learners.

\section{Conclusions}

The article discusses a mixed-method study that seeks to establish the participants' account of those English words that are difficult to pronounce by young EFL learners in the Years $3-7$ of primary school. The analysis of the participants' lists of PDWs in SPSS has yielded the frequencies of those words. Based upon the analysis of the participants' comments upon PDWs and the combined list of PDWs (see Tables $2-3$ ), it is evident that the participants draw their attention to the PDWs that contain those English sounds that do not exist in the phonological system of the Norwegian language, the young EFL learners' L1. In their comments, the participants make explicit references to the sounds $/ 3: /, / \theta /, / \mathrm{d} /, / \mathrm{r} /, / \mathrm{z} /$, and $/ \mathrm{w} /$ that are present in the PDWs, but not found in Norwegian. According to the participants, these sounds account for a substantial number of PDWs that are challenging to pronounce by young EFL learners. In this regard, these findings support previous research studies (e.g., Metruk 2018; Nowacka 2016; Szpyra-Kozłowska 2011, 2012; Szpyra-Kozłowska and Stasiak 2010), which point to the presence of $/ \mathrm{r} /, / \theta /, / \delta /$, and $/ \mathrm{w} /$ as a source of PDWs. The novelty of these findings, however, rests with those PDWs that involve /z/, as well as the $/ \mathrm{z} /-/ \mathrm{s} /$ contrast, which have not been described in the literature (Metruk 2018; Nowacka 2016; Szpyra-Kozłowska 2011, 2012).

Other novel findings involve the following. First, there are frequent PDWs (e.g., cheese, chocolate) with the word-initial affricate /t $\mathrm{f} /$, which appears to be routinely substituted for the English $/ \mathrm{J} /$ or the Norwegian retroflex fricative $/ \mathrm{s} /$. The source of these PDWs seems to be associated with the dialects of young learners' L1, bokmål or nynorsk. Second, in contrast to previous studies (e.g., Nowacka 2016; Porzuczek and Rojczyk 2017) word stress does not seem to be a substantial problem as a source of PDWs in oral classroom discourse by young EFL learners whose L1 is Norwegian.

In regard of the participants' comments and reflections concerning the sources of PDWs, it can be summarised that PDWs appear to be associated, predominantly, with a number of individual sounds (e.g., /3:/, / / /, /ð/,/r/, /z/, and $/ w /)$ and not with the suprasegmental units. None of the participants mentions word phrases in conjunction with the PDWs. Additionally, only 35\% of the participants provide a complex account of the sources of PDWs by referring to multiple problematic features in one PDW. For instance, those participants draw attention to several problematic-to-pronounce sounds in the PDWs birthday, thirty, third, etc., whereas $65 \%$ of the participants seem to concentrate on one problematic segmental feature per PDW.

From a linguo-didactic perspective, it is possible to formulate the following suggestions that might be relevant to the EFL teaching and learning in 
Norwegian primary school contexts: i) there appears to be a need to compile a list of PDWs that are reflective of young EFL learners' difficulties; ii) EFL teachers should be made aware of a set of PDWs that might be problematic to pronounce by young EFL learners. Additionally, further studies are needed to provide a deeper insight into PDWs that pose problems to young EFL learners whose L1 is Norwegian.

\section{Acknowledgements}

The author of the article wants to acknowledge 26 in-service primary school teachers whose participation in the study has been invaluable.

\section{References}

Bakken, Anja Synnøve, and Ragnhild Elisabeth Lund. 2018. Why should learners of English read? Norwegian English teachers' notions of EFL reading. Teaching and Teacher Education 70, 7887. https://doi.org/10.1016/j.tate.2017.11.002.

Brinton, Donna, Celce-Murcia, Marianne, and Janet Goodwin. 2010 (2nd ed.). Teaching pronunciation: A course book and reference guide. Cambridge: Cambridge University Press.

Copland, Fiona, Sue Garton, and Anne Burns. 2014. Challenges in teaching English to young learners: Global perspectives and local realities. Tesol Quarterly 48(4). 738-762. https://doi.org/10.1002/tesq.148.

Drew, Ion. 2009. Using the early years literacy programme in primary EFL Norwegian classrooms. In: Early learning of modern foreign languages: Processes and outcomes, se. by Marianne Nikolov. Bristol: Multilingual Matters, 108-120.

https://doi.org/10.21832/9781847691477-010

Drew, Ion, Oostdam, Ron and Han van Toorenburg. 2007. Teachers' experiences and perceptions of primary EFL in Norway and the Netherlands: a comparative study. European Journal of Teacher Education 30 (3), 319-341, https://doi.org/10.1080/02619760701486159

Howell, Peter, James Au-Yeung, Scott Yaruss, \& Kevin Eldridge. 2006. Phonetic difficulty and stuttering in English. Clinical Linguistics \& Phonetics, 20 (9), 703-716. https://doi.org/10.1080/02699200500390990.

Iverson, Gregory K. 1983. Korean /s/. Journal of Phonetics 11, 191-200. https://doi.org/10.1016/S0095-4470(19)30815-0.

Jarosz, Anna. 2019. English Pronunciation in L2 Instruction. The Case of Secondary School Learners. Cham: Springer. https://doi.org/10.1007/978-3-030-13892-9

Mellegård, Ingebjørg, and Karin Dahlberg Pettersen. 2012. Curriculum practice: English teachers' understanding and realisation of the new national curriculum, LK06. In: The Young Language Learner. Research-based Insights into Teaching and Learning, ed. by Angela Hasselgreen, Ion Drew and Bjørn Sørheim. Bergen: Fagbokforlaget, 207-218.

Neville, Colin. 2010 (2nd ed.) The Complete Guide to Referencing and Avoiding Plagiarism. Maidenhead: Open University Press. 
Olsen, Sonni. 1999. Errors and compensatory strategies: A study of grammar and vocabulary in texts written by Norwegian learners of English. System 27(2), 191-205.

https://doi.org/10.1016/S0346-251X(99)00016-0

Porzuczek, Andrzej. 2015. Handling Global and Local English Pronunciation Errors, In: Teaching and Researching the Pronunciation of English: Studies in Honour of Włodzimierz Sobkowiak, ed. by E. Waniek-Klimczak and M. Pawlak. [Second Language Learning and Teaching] London: Springer, 169-187.

Porzuczek, Andrzej and Arkadiusz Rojczyk. 2017. English word stress in Polish learners' speech production and metacompetence. Research in Language (15) 4. 313-323. https://doi.org/10.1515/rela-2017-0018.

Research in Language. 2019. Internet site at Sciendo [accessed on 1 August 2019]; https://content.sciendo.com/view/journals/rela/rela-overview.xml.

Rogerson-Revell, Pamela. 2011. English Phonology and Pronunciation Teaching. London, UK: Continuum.

Rugesæter, Kåre Nitter. 2014. Difficult contrasts: an analysis of phonemic distinctions in the English of young Norwegian learners seen against the backdrop of incidental foreign language learning. Acta Didactica Norge 8 (1). 1-20. https://doi.org/10.5617/adno.1102

Rugesæter, Kåre Nitter. 2012. Phonological competence in English among Norwegian pupils and implications for the teaching of pronunciation in the English classroom. In: The Young Language Learner. Research- based Insights into Teaching and Learning, ed. by Angela Hasselgreen, Ion Drew and Bjørn Sørheim. Bergen: Fagbokforlaget, 119-130.

Scheffler, Paweł, May Olaug Horverak, and Anna Domińska. 2018. English Instruction in Polish and Norwegian Secondary Schools: Convergent goals, divergent means. In: Challenges of Second and Foreign Language Education in a Globalized World. Studies in Honor of Krystyna Droździat-Szelest, ed. by Mirosław Pawlak and Anna Mystkowska-Wiertelak. Cham: Springer, 131-149. https://doi.org/10.1007/978-3-319-66975-5_9

Speitz, Heike. 2012. Experiences with an earlier start to modern foreign language other than English in Norway. In: The Young Language Learner. Research-based Insights into Teaching and Learning, ed. by Angela Hasselgreen, Ion Drew and Bjørn Sørheim. Bergen: Fagbokforlaget, 11-22.

SPSS IBM. 2011. IBM SPSS statistics for Windows, version 20.0. New York: IBM Corp.

Szpyra-Kozłowska, Jolanta. 2012. Mispronounced lexical items in Polish English of advanced learners. Research in Language 10 (2), 243-256. https://doi.org/10.2478/v10015-011-0042-9

Szpyra-Kozłowska, Jolanta. 2011. Phonetically difficult words in intermediate learners' English.

In: Speaking and Instructed Foreign Language Acquisition, ed. by M. Pawlak, E. WaniekKlimczak, \& J. Majer. Bristol: Multilingual Matters, 286-299.

https://doi.org/10.21832/9781847694126-021

Tergujeff, Elina. English Pronunciation Teaching: Four Case Studies from Finland. Journal of Language Teaching \& Research 3 (4), 599-607. https://doi.org/10.4304/jltr.3.4.599-607

Trecca, Fabio, et al. 2019. Segmentation of Highly Vocalic Speech Via Statistical Learning: Initial

Results From Danish, Norwegian, and English. Language Learning 69 (1), 143-176.

https://doi.org/10.1111/lang.12325

Walsh, Steve. 2011. Exploring classroom discourse: Language in action. London/New York: Routledge. https://doi.org/10.4324/9780203827826 
Wingate Marcel E. 2002. Foundations of stuttering. San Diego: Academic Press. https://doi.org/10.1016/B978-012759451-4/50006-9

Zhang, Shumei. 2009. The role of input, interaction, and output in the development of oral fluency. English Language Teaching, 2(4), 91-100. https://doi.org/10.5539/elt.v2n4p91 